\title{
Mechanisms and Diversity of Resistance to Insect Pests in Wild Relatives of Groundnut
}

\author{
H. C. SHARMA, ${ }^{1}$ G. PAMPAPATHY, S. L. DWIVEDI, AND L. J. REDDY
}

International Crops Research Institute for the Semi-Arid Tropics (ICRISAT), Patancheru 502 324, Andhra Pradesh, India

J. Econ. Entomol. 96(6): 1886-1897 (2003)

\begin{abstract}
The levels of resistance to insect pests in cultivated groundnut (Arachis hypogaea) germplasm are quite low, and therefore, we screened 30 accessions of Arachis spp. and 12 derived lines for resistance to insect pests under field and greenhouse conditions. Accessions belonging to Arachis cardenasii, Arachis duranensis, Arachis kempff-mercadoi, Arachis monticola, Arachis stenosperma, Arachis paraguariensis, Arachis pusilla, and Arachis triseminata showed multiple resistance to the leaf miner Aproaerema modicella, Helicoverpa armigera, Empoasca kerri, and to rust, Puccnia arachidis Speg., and late leaf spot, Cercosporidium personatum (Berk. et Curt.). Arachis cardenasii (ICG 8216), Arachis ipaensis (ICG 8206), A. paraguariensis (ICG 8130), and Arachis appressipila (ICG 8946) showed resistance to leaf feeding and antibiosis to Spodoptera litura under no-choice conditions. Six lines, derived from wild relatives, showed resistance to H. armigera and S. litura, and/or leaf miner. Plant morphological characteristics such as main stem thickness, hypanthium length, leaflet shape and length, leaf hairiness, standard petal length and petal markings, basal leaflet width, main stem thickness and hairiness, stipule adnation length and width, and peg length showed significant correlation and/or regression coefficients with damage by $H$. armigera, S. litura, and leafhoppers, and these traits can possibly be used as markers to select for resistance to these insect pests. Principal component analysis placed the Arachis spp. accessions into five groups, and these differences can be exploited to diversify resistance to the target insect pests in groundnut.
\end{abstract}

KEY WORDS groundnut, Arachis spp., Helicoverpa, Spodoptera, resistance

GROUNDNUT IS AN IMPORTANT crop in the semiarid tropics, and it plays an important role in human diet, in both developed and developing countries. Despite its high production potential, the actual yields on farmer's fields are quite low largely because of insect pests and diseases. More than 350 species of insects damage this crop in different parts of the world (Stalker and Campbell 1983), of which white grubs (in India, Holotrichia consanguinea Blanch. and Holotrichia serrata F.; and in Africa, Eulepida mashona Arrow), aphids (Aphis craccivora Koch, a vector of groundnut rosette virus in Africa), thrips [Scirtothrips dorsalis Hood, Caliothrips indicus Bagnall, Frankliniella schultzei (Trybom), and Thrips palmi, a vector of peanut bud necrosis virus in India], leafhoppers (Empoasca kerri Pruthi), leaf miner (Aproaerema modicella Deventer), armyworms [Spodoptera litura F. in India, Spodoptera littoralis Boisduval in Africa, and Spodoptera frugiperda (J.E. Smith) in North and South America], cotton bollworm/corn earworm (Helicoverpa zea Boddie in North and South America, and Helicoverpa armigera (Hübner) in Asia, Africa, and Australia), and termites (Microtermes spp. and Odontotermes spp.) are most important. In the semiarid tropics, insect pests cause

\footnotetext{
1'E-mail: H.sharma@cgiar.org.
}

an estimated loss of $\$ 720$ million annually (ICRISAT 1992). In addition, aphids and thrips also serve as vectors of viral diseases of groundnut. Heavy infestations, early in the growing season, result in serious losses in haulm (leaves and stem) and kernel yields (Panchabhavi and Nethradani Raj 1987, Wightman et al. 1990). The effects of defoliation on kernel yields are greater in the post-rainy crop than in the rainy season crop, because of slower plant growth as a result of cooler climates (Wightman et al. 1990).

Traditionally, insect control in groundnut is dependent on insecticides. With the development of insecticide resistance in insect populations, occurrence of pesticide residues in food and food products, and adverse effects of pesticide use on the environment, the alternative methods of pest control have begun to receive considerable attention. Host plant resistance is one of the most economical and environment-friendly methods of keeping pest populations below economic injury levels (EILs). In the germplasm accessions of cultivated groundnut screened to date, moderate levels of resistance have been observed against A. modicella, S. litura, S. frugiperda, and white grubs (Wightman and Amin 1988, Wightman et al. 1990, Lynch et al. 1981). Some attempts have also been made to identify sources of resistance in the wild relatives of 
Table 1. Damage rating scales for evaluating resistance/susceptibility of Arachis spp. to $\mathrm{H}$. armigera, S. litura, leafhoppers, thrips, and leaf diseases

\begin{tabular}{|c|c|c|c|c|}
\hline $\begin{array}{l}\text { Damage } \\
\text { rating }\end{array}$ & $\begin{array}{l}\text { H. armigera } / \mathrm{S} \text {. litura } \\
\text { (\% leaf area damaged })\end{array}$ & $\begin{array}{l}\text { Leafhoppers } \\
\text { (leaf yellowing) }\end{array}$ & Thrips (leaf rasping) & $\begin{array}{c}\text { Leaf diseases } \\
(\% \text { leaf area infected })\end{array}$ \\
\hline 1 & $<10$ & $<10 \%$ leaves with slight yellowing & $<10 \%$ leaves with rasping & $<10$ \\
\hline 2 & $11-20$ & $\begin{array}{l}11-20 \% \text { leaves with pinhead sized } \\
\text { yellow spots }\end{array}$ & $11-20 \%$ leaves with rasping & $11-20$ \\
\hline 3 & $21-30$ & $\begin{array}{l}21-30 \% \text { leaves with } 2-3 \mathrm{~mm} \\
\text { diameter yellow spots }\end{array}$ & $21-30 \%$ leaves with rasping & $21-30$ \\
\hline 4 & $31-40$ & $\begin{array}{l}31-40 \% \text { leaves with } 3-4 \mathrm{~mm} \\
\text { yellow spots }\end{array}$ & $31-40 \%$ leaves with rasping & $31-40$ \\
\hline 5 & $41-50$ & $\begin{array}{l}41-50 \% \text { leaves with } 4-5 \mathrm{~mm} \\
\text { yellow spots }\end{array}$ & $41-50 \%$ leaves with rasping & $41-50$ \\
\hline 6 & $51-60$ & $\begin{array}{l}51-60 \% \text { leaves with } 5-6 \mathrm{~mm} \\
\text { yellow spots }\end{array}$ & $51-60 \%$ leaves with rasping & $51-60$ \\
\hline 7 & $61-70$ & $\begin{array}{l}61-70 \% \text { leaves with } 7-8 \mathrm{~mm} \\
\text { yellow spots }\end{array}$ & $61-70 \%$ leaves with rasping & $61-70$ \\
\hline 8 & $71-80$ & $\begin{array}{l}71-80 \% \text { leaves with } 8-9 \mathrm{~mm} \\
\text { yellow spots }\end{array}$ & $71-80 \%$ leaves with rasping & $71-80$ \\
\hline 9 & $>80$ & $\begin{array}{l}>80 \% \text { leaves with }>10 \mathrm{~mm} \text { sized } \\
\quad \text { yellow spots }\end{array}$ & $>80 \%$ leaves with rasping & $>80$ \\
\hline
\end{tabular}

groundnut (Johnson et al. 1977, Lynch et al. 1981, Amin 1985, Lynch, 1990, Stevenson et al. 1993). However, many of these evaluations were confined to single accessions of the species examined, and at times, there is no information on the accessions tested. Because there can be considerable variation in susceptibility to insects among different accessions of the same species, we selected a wide range of accessions from the Arachis spp. to identify lines with high levels of resistance to the target pests, and examine the variation in the susceptibility of different accessions to the target insect pests.

Considerable progress has been made at the International Crops Research Institute for the Semi-Arid Tropics (ICRISAT) in introgressing genes from the wild relatives into cultivated groundnut for resistance to rust, Puccnia arachidis Speg., and late leaf spot, Cercosporidium personatum (Berk. et Curt.). Therefore, we selected a set of twelve derivatives of groundnut derived from wild relatives to examine whether these derivatives are less susceptible to insect pests than commercial cultivars. Because there is considerable variation in insect infestations under field conditions, we also confirmed the reaction of different accessions to $S$. litura under uniform insect pressure in the greenhouse.

\section{Materials and Methods}

Field Screening. Thirty accessions of Arachis spp. were evaluated for resistance to insects for use in interspecific hybridization. Five genotypes of Arachis hypogaea (TMV 2-commercial check, ICGV 87160 and ICGV 86031-improved lines with resistance to leaf diseases and S. litura, respectively, and M 13 and NCAc 343-resistant to aphids, leafhoppers, and thrips) were included as controls. The crop was raised on light red sandy soil (Alfisols) during the 1999-2000 rainy and post-rainy seasons. There were three replications in a randomized complete block design. Each plot had four rows, $2 \mathrm{~m}$ long, and the material was planted on ridges, $75 \mathrm{~cm}$ apart. Diammonium phosphate was applied as a basal fertilizer at the rate of 100 $\mathrm{kg} / \mathrm{ha}$. Urea was applied as a top dressing once during the rainy season in September, and during February after the rainy season. The seeds were treated with Ethrel (Imperial Chemical Industries, Berks, UK) before sowing to break seed dormancy. The seeds were hand sown $5-7 \mathrm{~cm}$ below the soil surface at a spacing of $15 \mathrm{~cm}$ between plants. No insecticide was applied in the experimental plots. The crop was weeded by hand when required, maintained under rainfed conditions during the rainy season, but irrigated at 15-d intervals during the post-rainy season. At the end of the rainy season in November, the cultivated groundnuts were harvested, and plots were resown after $30 \mathrm{~d}$. Plots of wild relatives continued to grow until April 2000. Aluminum strips (15 cm high) were placed around the plots of wild relatives to prevent them from spreading into the neighboring plots. Data were recorded on leaf miner damage (\% leaflets with leaf miner damage), leaf feeding by $H$. armigera and $S$. litura, leaf yellowing as a result of leafhopper ( $E$. kerri), leaf rasping because of thrips (mostly $S$. dorsalis), and severity of infection by rust (Puccnia arachidis) and late leaf spot (Cercosporidium personatum). Damage rating scales for evaluating resistance/susceptibility of Arachis spp. to H. armigera, S. litura, leafhoppers, thrips, and leaf diseases (rust and late leaf spot) are described in Table 1.

Data were also recorded on plant morphological traits such as apical leaflet shape on the main stem, primary laterals, and basal leaflet on primary laterals $(1=$ cuneate, $5=$ narrow elliptic, $9=$ ovate, $12=$ oblong-lanceolate, $13=$ lanceolate, and $14=$ linearlanceolate), bristles on leaflet margin $(1=$ absent and 3 = few $)$, flowers on main stem $(1=$ absent, $2=$ present $)$, growth habit $(1=$ procumbent- $1,2=$ procumbent-2, 3 = decumbent-1, $4=$ decumbent- $2,5=$ decumbent- 3 , and 6 = erect $)$, leaflet color $(1=$ yel- 
low-green, 2 = light green, $3=$ green, $4=$ dark green, and $5=$ bluish-green), leaflet hairiness on the main stem ( 1 = glabrous on both surfaces; $2=$ almost glabrous above, hairs below; $5=$ almost glabrous below, hairs and bristles above; $8=$ wooly without bristles; $9=$ wooly with bristles at least on one surface), standard petal markings $(1=$ white, $2=$ lemon, $3=$ yellow, $4=$ orange yellow, $5=$ orange, $6=$ dark orange, $7=$ garnet $)$, main stem hairiness $(1=$ glabrous, $3=$ subglabrous, $5=$ moderately hairy, $7=$ very hairy, $9=$ wooly $)$, stem pigmentation $(1=$ absent, $2=$ present $)$, and flowers on the main stem $(1=$ simple, $2=$ compound). Linear measurements of different plant parts and maturity in days were recorded (IBPGR 1992, ICRISAT 1992).

In another trial, 12 interspecific derivatives involving A. hypogaea and wild relatives [one derivative of A. hypogaea $\times$ Arachis cardenasii $\times$ Arachis batizocoii, five of A. hypogaea $\times A$. cardenasii, two of $A$. hypogaea $\times$ Arachis duranensis $\times$ Arachis stenosperma, one of A. hypogaea $\times$ Arachis villosa, and two of $A$. hypogaea $\times A$. batizocoii $\times A$. duranensis $)$, and eight cultivars of $A$. hypogaea were also evaluated for resistance to insects to explore the possibilities of identifying lines with less susceptibility to insects through wide hybridization. The material was planted in 4-row plots and $2 \mathrm{~m}$ long. There were three replications arranged in a randomized complete block design. The crop was raised on Alfisols soil during the 1999 rainy season and on Vertisols soil during the 1999-2000 post-rainy seasons, and the 2000 rainy season. Normal agronomic practices were followed for raising the crop as described above. Observations were recorded on damage by leaf miner, $H$. armigera, S. litura, leafhoppers, rust and late leaf spot, and peanut bud necrosis disease, as described above. At crop maturity, the field was irrigated and the pods were pulled out after $2 \mathrm{~d}$. Plants were dried in the field for $3 \mathrm{~d}$, and then the pods were separated from the plant by hand. Pods were dried in the sun for $5 \mathrm{~d}$, and then the dry weight of the pods harvested from each plot was recorded and expressed as kg per hectare.

Screening for Resistance to S. litura Under NoChoice Conditions in the Greenhouse. To confirm the reaction of different accessions observed under field conditions, 28 accessions of wild relatives, and three checks of the cultivated groundnut were screened for resistance to $S$. litura under no-choice conditions in the greenhouse (Sharma et al. 2002). Twelve derivatives of wild relatives and eight cultivated genotypes were also evaluated for resistance to S. litura. Groundnut plants were raised in the greenhouse in plastic pots (30 $\mathrm{cm}$ diameter, $30 \mathrm{~cm}$ deep). The pots were filled with a potting mixture of soil (Alfisols), sand, and farmyard manure $(2: 1: 1)$. Five seeds were sown in each pot at $7 \mathrm{~cm}$ below the soil surface. The plants were watered as needed. Two seedlings with similar growth were retained in each pot at $10 \mathrm{~d}$ after seedling emergence. The greenhouse was cooled by desert coolers to maintain the temperature at $28 \pm 5^{\circ} \mathrm{C}$ and $\mathrm{RH}>65 \%$. The culture of $\mathrm{S}$. litura collected from the field was maintained on artificial diet as described by
Taneja and Leuschner (1985). The pupae were kept in moistened sand. Upon emergence, the moths were released in a $30 \times 30 \times 30 \mathrm{~cm}$ screened cage for oviposition and fed on $10 \%$ honey solution. The moths laid eggs on the blotting paper strips $(30 \times 10 \mathrm{~cm})$, which were changed daily. The egg masses were sterilized in $2 \%$ sodium hypochlorite solution. First- to third-instar larvae were reared in groups of 100 larvae in 1-liter plastic jars. The mature larvae (fourth instars) were reared individually in 6-cell wells $(3.5 \mathrm{~cm}$ diameter and $2 \mathrm{~cm}$ deep). The culture was maintained in the laboratory throughout the year, and the neonates were used for experiments when needed.

Plants were infested at $15 \mathrm{~d}$ after seedling emergence. One plant in each pot was covered with a plastic jar cage (11 cm diameter, $26 \mathrm{~cm}$ in height) with two wire-mesh screened windows ( $4 \mathrm{~cm}$ diameter) on the sides (Sharma et al. 2002). The top of the plastic jar cage was covered with a lid fitted with wire-mesh screen. First-instar larvae were placed in $10-\mathrm{ml}$ vials (10 in each vial) and taken to the greenhouse for infestation. Insects were released inside the cage, and the lower end (up to $2 \mathrm{~cm}$ ) of the cage was pushed into the soil. One plant was infested with the larvae inside the cage whereas the other was left as an uninfested control. There were three replications in a randomized complete block design. Observations were recorded at $7 \mathrm{~d}$ after infestation. The numbers of larvae surviving on each plant were recorded, and these larvae were placed in plastic cups. Larval weights were recorded $4 \mathrm{~h}$ after termination of the experiment. Plants were rated for leaf damage visually on a 1-9 rating scale (Table 1). Plants were then excised at the base, and fresh weight of infested and uninfested plants was measured separately. Plants were dried in an oven at $65^{\circ} \mathrm{C}$ for $5 \mathrm{~d}$, and dry weights of the infested and uninfested plants also were measured. Loss in plant biomass as a result of feeding by the S. litura larvae was computed in relation to the biomass of the uninfested control plant in each pot.

Statistical Analysis. Data were subjected to analysis of variance using GENSTAT release 4.2 (GENSTAT 2000). The significance of differences between the treatments was measured by $F$-test at $P=0.05$, and the treatment means were compared using the least significant difference at $P=0.05$. Data on 21 accessions for insect damage and 30 plant morphological characteristics were subjected to correlation analysis. The plant traits showing significant correlations with insect damage were subjected to stepwise regression analysis to identify plant traits, which exercise maximum influence on expression of resistance/susceptibility to different insect pests. The same data set was also subjected to principal component analysis (Iezzoni and Pitts 1991) to categorize the genotypes into different groups based on the first two principal components that explained maximum variability in the genotypes tested. Based on this analysis, the genotypes placed into different groups have different combinations of characters, are diverse, and can be exploited for increasing the diversity for resistance to the target insect pests or any other trait of interest. 
Table 2. Relative susceptibility of 30 accessions of wild Arachis spp. and five groundnut cultivars to leaf miner, Helicoverpa and leafhoppers under field conditions

\begin{tabular}{|c|c|c|c|c|c|}
\hline \multirow{2}{*}{$\begin{array}{l}\text { Accession } \\
\text { number }\end{array}$} & \multirow{2}{*}{ Species $^{a}$} & \multirow{2}{*}{$\begin{array}{c}\text { Leaf miner damaged } \\
\text { leaflets }(\%)\end{array}$} & \multicolumn{3}{|c|}{ Damage rating $^{a}$} \\
\hline & & & Helicoverpa & Leafhoppers & Foliar diseases \\
\hline ICG 11551 & A. benensis & 4.6 & 1.0 & 1.0 & 1.5 \\
\hline ICG 8216 & A. cardenasii & 5.2 & 1.0 & 2.0 & 1.0 \\
\hline ICG 8201 & A. duranensis & 3.9 & 2.3 & 1.3 & 2.0 \\
\hline ICG 8203 & A. duranensis & 8.4 & 2.8 & 1.2 & 2.0 \\
\hline ICG 11555 & A. duranensis & 7.8 & 1.0 & 1.0 & 1.0 \\
\hline ICG 13242 & A. duranensis & 9.2 & 1.8 & 1.0 & 2.0 \\
\hline ICG 15171 & A. duranensis & 7.4 & 1.3 & 1.0 & 1.8 \\
\hline ICG 8195 & A. duranensis & 9.4 & 1.0 & 1.0 & 1.5 \\
\hline ICG 11550 & A. duranensis & 9.7 & 1.3 & 1.3 & 1.0 \\
\hline ICG 8190 & A. hoehnei & 8.1 & 1.0 & 1.0 & 1.0 \\
\hline ICG 8206 & A. ipaensis & 20.4 & 1.0 & 1.0 & 2.0 \\
\hline ICG 8164 & A. kempff-mercadoi & 8.8 & 1.0 & 1.3 & 0.0 \\
\hline ICG 8959 & A. kempff-mercadoi & 6.5 & 1.0 & 1.0 & 0.5 \\
\hline ICG 8197 & A. monticola & 6.1 & 1.8 & 1.0 & 4.0 \\
\hline ICG 13177 & A. monticola & 13.4 & 1.5 & 1.0 & 3.0 \\
\hline ICG 13178 & A. monticola & 8.5 & 3.0 & 1.0 & 4.0 \\
\hline ICG 8125 & A. stenosperma & 9.3 & 1.5 & 1.0 & 0.5 \\
\hline ICG 13171 & A. stenosperma & 6.9 & 1.3 & 1.0 & 3.0 \\
\hline ICG 13173 & A. stenosperma & 5.3 & 1.0 & 1.0 & 0.5 \\
\hline ICG 8130 & A. paraguariensis & 22.5 & 1.0 & 0.5 & 0.0 \\
\hline ICG 8963 & A. paraguariensis & 4.0 & 1.0 & 0.5 & 0.0 \\
\hline ICG 8970 & A. paraguariensis & 12.8 & 1.3 & 1.0 & 0.0 \\
\hline ICG 8215 & A. stenophylla & 24.2 & 1.0 & 1.0 & 0.0 \\
\hline ICG 13212 & A. pusilla & 6.5 & 1.0 & 2.0 & 1.0 \\
\hline ICG 14915 & A. sylvestris & 10.2 & 1.0 & 1.0 & 2.0 \\
\hline ICG 8945 & A. appressipila & 11.4 & 1.0 & 0.5 & 0.5 \\
\hline ICG 8946 & A. appressipila & 19.3 & 1.0 & 1.0 & 0.0 \\
\hline ICG 11557 & A. matiensis & 10.2 & 1.5 & 1.0 & 0.5 \\
\hline ICG 8904 & A. rigonii & 10.2 & 1.0 & 1.0 & 0.0 \\
\hline ICG 8131 & A. triseminata & 4.7 & 1.0 & 1.0 & 0.5 \\
\hline ICGV86031 & A. hypogaea & 17.2 & 2.5 & 1.0 & 6.5 \\
\hline TMV 2 & A. hypogaea & 12.8 & 5.0 & 0.8 & 9.0 \\
\hline M 13 & A. hypogaea & 6.4 & 2.0 & 3.5 & 3.5 \\
\hline NCAc 343 & A. hypogaea & 6.9 & 1.5 & 3.5 & 2.0 \\
\hline ICGV 87160 & A. hypogaea & 20.0 & 2.0 & 3.0 & 5.0 \\
\hline SE & & \pm 5.1 & \pm 0.3 & \pm 0.3 & \pm 0.8 \\
\hline $\operatorname{LSD}(P=0.05)$ & & 14.94 & 0.97 & 0.83 & 2.19 \\
\hline$F(\mathrm{df}=69)$ & & 1.25 & 5.92 & 6.17 & 6.90 \\
\hline$P$ & & 0.298 & 0.001 & 0.001 & 0.001 \\
\hline
\end{tabular}

${ }^{a}$ Damage rating, see Table 1.

\section{Results}

Evaluation of Wild Arachis spp. for Insect Resistance Under Multi-Choice Field Conditions. There was considerable variation in the relative susceptibility of different accessions of A. cardenasii, A. duranensis, Arachis kempff-mercadoi, Arachis monticola, A. stenosperma, Arachis paraguariensis, and Arachis appressipila, for which more than one accession was tested for resistance to insects. There were significant differences in leaf feeding by $H$. armigera $(F=5.92$, $\mathrm{df}=69, P<0.001)$, leafhoppers $(F=6.17, \mathrm{df}=69, P<$ $0.001)$, and rust/late leaf spot severity $(F=6.90, \mathrm{df}=$ $69, P<0.001$ ) (Table 2). Arachis cardenasii (ICG 8216), A. duranensis (ICG 11555, ICG 15171, ICG 8195, and ICG 11550), A. kempff-mercadoi (ICG 8959), A. monticola (ICG 8197), A. stenosperma (ICG 13173), A. paraguariensis (ICG 8963), A. pusilla (ICG 13212), and Arachis triseminata (ICG 8131) accessions showed multiple resistance to leaf miner $(<10 \%$ leaflets with leaf miner damage compared with $17.2 \%$ in ICGV 86031), H. armigera (damage rating $<2.5$ compared with 5.0 in TMV 2), leafhoppers (damage rating $<2.0$ compared with 3.5 in M 13 and NCAc 343), and rust and late leaf spot (damage rating $<2.0$ compared with 9.0 in TMV 2). Some accessions belonging to $A$. $d u$ ranensis (ICG 8203), Arachis ipaensis (ICG 8206), A. monticola (ICG 13177 and ICG 13178), and A. appressipila (ICG 8945 and ICG 8946) showed a susceptible reaction to leaf miner, Helicoverpa, and/or leafhoppers. A number of accessions showed high levels of resistance to leafhoppers and rust/late leaf spot. Among the cultivated genotypes of A. hypogaea, M 13 and NCAc 343 were less susceptible to $H$. armigera than TMV 2. There was a significant and positive correlation between leaf damage by $H$. armigera and severity of rust and late leaf spot $(r=0.54, P<0.001)$. Therefore, it is important to define the target regions and the key pest problems when developing ground- 
Table 3. Relative susceptibility of 28 accessions of Arachis spp. and three groundnut cultivars to Spodoptera litura under no-choice cage tests in the greenhouse

\begin{tabular}{|c|c|c|c|c|c|c|c|}
\hline \multirow[t]{2}{*}{ Accession number } & \multirow[t]{2}{*}{ Species } & \multirow[t]{2}{*}{$\begin{array}{l}\text { Leaf damage } \\
\text { rating }\end{array}$} & \multicolumn{2}{|c|}{$\begin{array}{c}\text { Seedling } \\
\text { weight loss } \\
(\%)\end{array}$} & \multirow[t]{2}{*}{$\begin{array}{c}\text { Larval } \\
\text { weight (mg) }\end{array}$} & \multirow[t]{2}{*}{$\begin{array}{c}\text { Larval } \\
\text { survival }(\%)\end{array}$} & \multirow[t]{2}{*}{$\begin{array}{l}\text { Resistance } \\
\text { index }\end{array}$} \\
\hline & & & Wet & Dry & & & \\
\hline ICG 11551 & A. benensis & 7.3 & 49.3 & 40.7 & 24.0 & 73.3 & 8.8 \\
\hline ICG 8216 & A. cardenasii & 4.7 & 14.6 & 16.5 & 6.8 & 63.3 & 0.9 \\
\hline ICG 8195 & A. duranensis & 6.0 & 42.5 & 35 & 23.0 & 40.0 & 2.3 \\
\hline ICG 8201 & A. duranensis & 4.3 & 45.7 & 42 & 31.5 & 70.0 & 4.8 \\
\hline ICG 8203 & A. duranensis & 5.3 & 38.5 & 40.7 & 74.3 & 43.3 & 8.0 \\
\hline ICG 11550 & A. duranensis & 8.3 & 59.4 & 52 & 38.1 & 66.7 & 12.2 \\
\hline ICG 11555 & A. duranensis & 7.0 & 38.7 & 35 & 38.1 & 73.3 & 11.9 \\
\hline ICG 13242 & A. duranensis & 5.7 & 26.5 & 25.5 & 50.0 & 60.0 & 10.8 \\
\hline ICG 15171 & A. duranensis & 6.7 & 53.2 & 47.7 & 24.1 & 66.7 & 7.6 \\
\hline ICG 8190 & A. hoehnei & 5.3 & 40.1 & 48.9 & 18.5 & 53.3 & 2.0 \\
\hline ICG 8206 & A. ipaensis & 2.7 & 23 & 20 & 10.0 & 46.7 & 0.5 \\
\hline ICG 8164 & A. kempff-mercadoi & 7.7 & 30.7 & 26.6 & 33.8 & 70.0 & 12.3 \\
\hline ICG 8959 & A. kempff-mercadoi & 4.7 & 43 & 39.8 & 17.4 & 66.7 & 2.5 \\
\hline ICG 8197 & A. monticola & 6.7 & 42.4 & 40.8 & 62.1 & 66.7 & 15.9 \\
\hline ICG 13177 & A. monticola & 7.7 & 64.7 & 68.5 & 54.6 & 73.3 & 15.7 \\
\hline ICG 13178 & A. monticola & 8.3 & 51.8 & 58.2 & 70.1 & 56.7 & 15.8 \\
\hline ICG 8125 & A. stenosperma & 6.0 & 48.7 & 42.6 & 19.0 & 70.0 & 4.7 \\
\hline ICG 13171 & A. stenosperma & 6.3 & 41.8 & 44.4 & 47.8 & 53.3 & 6.4 \\
\hline ICG 13173 & A. stenosperma & 6.4 & 52.5 & 40.8 & 33.4 & 73.3 & 7.6 \\
\hline ICG 8130 & A. paraguariensis & 5.7 & 15.8 & 10.6 & 8.1 & 60.0 & 1.9 \\
\hline ICG 8970 & A. paraguariensis & 4.7 & 34.9 & 36.2 & 30.9 & 50.0 & 3.5 \\
\hline ICG 8215 & A. stenophylla & 3.0 & 24.3 & 26.9 & 10.3 & 50.0 & 0.8 \\
\hline ICG 13212 & A. pusilla & 9.0 & 65.4 & 68.7 & 27.5 & 76.7 & 14.6 \\
\hline ICG 14915 & A. sylvestris & 4.0 & 28.3 & 45.8 & 7.0 & 26.7 & 0.5 \\
\hline ICG 8945 & A. appressipila & 2.7 & 33.1 & 29.7 & 12.6 & 60.0 & 1.0 \\
\hline ICG 8946 & A. appressipila & 1.3 & 19.8 & 27.7 & 6.3 & 50.0 & 0.3 \\
\hline ICG 8904 & A. rigonii & 5.3 & 46.9 & 39.1 & 28.7 & 60.0 & 4.8 \\
\hline ICG 8131 & A. triseminata & 3.3 & 32.1 & 30.7 & 9.9 & 56.7 & 0.8 \\
\hline ROBUT 33-1 & & 6.0 & 21 & 25.8 & 75.5 & 40.0 & 7.9 \\
\hline ICGV 86699 & & 9.0 & 51.7 & 51.8 & 68.5 & 80.0 & 18.8 \\
\hline TMV 2 & & 7.0 & 47.5 & 54.4 & 100.1 & 56.7 & 16.3 \\
\hline SE & & \pm 0.8 & \pm 12.3 & \pm 12.2 & \pm 8.2 & \pm 9.5 & \pm 3.0 \\
\hline $\operatorname{LSD}(P=0.05)$ & & 2.13 & 34.99 & 34.52 & 23.34 & 27.01 & 8.6 \\
\hline$F(\mathrm{df}=92)$ & & 6.52 & 1.24 & 1.27 & 9.2 & 1.73 & 3.7 \\
\hline$P$ & & 0.001 & 0.24 & 0.22 & 0.001 & 0.04 & 0.001 \\
\hline
\end{tabular}

Damage rating, see Table 1.

nut cultivars with resistance to insect pests so that breeding for resistance to one pest does not lead to increased susceptibility to another pest.

Evaluation of Arachis spp. for Resistance to S. litura, Under No-Choice Conditions in the Greenhouse. Under no-choice cage tests in the greenhouse, there were significant differences $(\mathrm{df}=92)$ in leaf feeding $(F=$ $6.52, P=0.001)$, larval weights $(F=9.20, P=0.001)$, and larval survival $(F=1.73, P=0.04)$ of S. litura on different accessions of wild Arachis spp. (Table 3). Accessions belonging to A. cardenasii (ICG 8216), A. duranensis (ICG 13242), A. ipaensis (ICG 8206), A. paraguariensis (ICG 8130), and A. appressipila (ICG 8946) showed resistance to leaf feeding by $S$. litura (damage rating $<5.7$, and $<28 \%$ loss in plant biomass compared with a damage rating of 7.0 and $47.5-54.4 \%$ loss in plant biomass in TMV 2). However, the differences in percentage loss in plant biomass were not significant $(P=0.24$ and 0.22 , respectively, for the wet and dry weight basis) (Table 3). These lines also showed high levels of antibiosis to S. litura larvae (larval weight $<50 \mathrm{mg}$ compared with $100.1 \mathrm{mg}$ on TMV 2, and larval survival $<63.3 \%$ compared with $80 \%$ survival on ICGV 86699 at $7 \mathrm{~d}$ after infestation). Low larval survival was also recorded on TMV 2 as a result of possible cannibalism among the larvae because of extensive feeding resulting in limited food supply. Low levels of leaf feeding were also observed on ICG 8201, ICG 8959, ICG 8970, ICG 8215, ICG 14915, ICG 8945, and ICG 8131. Very high levels of antibiosis (larval weights $<25 \mathrm{mg}$ per larva compared with $>100$ mg per larva on TMV 2) were observed in accessions belonging to Arachis benensis (ICG 11551), A. cardenasii (ICG 8216), A. duranensis (ICG 8195 and ICG 15171), Arachis hoehnei (ICG 8190), A. ipaensis (ICG 8206), A. kempff-mercadoi (ICG 8959), A. paraguariensis (ICG 8130), A. stenophylla (ICG 8215), Arachis sylvestris (ICG 14915), A. appressipila (ICG 8945 and ICG 8946), and A. triseminata (ICG 8131). Some of the accessions suffered heavy leaf feeding, although they showed antibiosis to larvae resulting in slow growth of the larvae possibly because of poor nutritional quality of the food and/or presence of secondary plant substances that might inhibit larval growth. Resistance index based on leaf feeding, weight of the larvae, and larval survival indicated that accessions belonging to 
Table 4. Relative susceptibility of 12 lines derived from wild Arachis spp. and eight cultivated groundnut genotypes to leaf miner, Helicoverpa spodoptera, and rust/late leaf spot under field conditions

\begin{tabular}{|c|c|c|c|c|c|c|c|}
\hline \multirow{3}{*}{ Genotype } & \multirow{3}{*}{ Pedigree $^{a}$} & \multirow{3}{*}{$\begin{array}{l}\begin{array}{l}\text { Leafminer } \\
\text { (\% leaflets } \\
\text { damaged) }\end{array} \\
1999\end{array}$} & \multicolumn{3}{|c|}{ Damage rating $^{b}$} & \multirow{2}{*}{\multicolumn{2}{|c|}{ Pod yield (kg per ha) }} \\
\hline & & & \multirow{2}{*}{$\begin{array}{c}\text { H. armigera } \\
1999\end{array}$} & \multirow{2}{*}{$\begin{array}{l}\text { S. litura } \\
1999 / 00\end{array}$} & \multirow{2}{*}{$\begin{array}{c}\begin{array}{c}\text { Foliar } \\
\text { diseases }\end{array} \\
1999\end{array}$} & & \\
\hline & & & & & & 1999 & $1999 / 00$ \\
\hline ICGV 99259 & Chico $\times[$ Shulamith $\times(\mathrm{Ac} \times \mathrm{Ab})$ & 5.6 & 1.2 & 2.3 & 2.0 & 686 & 343 \\
\hline ICGV 99260 & ICGMS $42 \times(\mathrm{Ah} \times \mathrm{Ac})$ & 11.3 & 3.3 & 2.8 & 5.0 & 689 & 498 \\
\hline ICGV 99006 & $\mathrm{Ah} \times \mathrm{Ac}$ & 10.9 & 2.7 & 2.2 & 8.7 & 665 & 494 \\
\hline ICGV 99007 & $\mathrm{Ah} \times \mathrm{Ac}$ & 6.5 & 1.7 & 2.7 & 2.3 & 932 & 296 \\
\hline ICGV 99001 & $\mathrm{Ah} \times(\mathrm{Ad} \times \mathrm{As})$ & 8.9 & 2.0 & 2.3 & 5.0 & 604 & 444 \\
\hline ICGV 99009 & Robut $33-1 \times A v$ & 4.9 & 1.7 & 1.8 & 2.3 & 979 & 363 \\
\hline ICGV 99002 & $($ Chico $\times$ Shulamith $) \times($ Aco $\times$ Ab $)$ & 5.0 & 1.0 & 1.7 & 2.0 & 969 & 366 \\
\hline ICGV 99003 & $\mathrm{Ah} \times(\mathrm{Ad} \times \mathrm{As})$ & 5.9 & 1.0 & 2.3 & 2.0 & 828 & 314 \\
\hline ICGV 99010 & $(\mathrm{Ah} \times \mathrm{Ac}) \times \mathrm{T} 900$ & 9.0 & 2.8 & 1.7 & 7.3 & 581 & 408 \\
\hline ICGV 99004 & TMV $2 \times(\mathrm{Ah} \times \mathrm{Ac})$ & 5.3 & 1.8 & 1.5 & 6.0 & 790 & 507 \\
\hline ICGV 99005 & TMV $2 \times(\mathrm{Ah} \times \mathrm{Ab} \times \mathrm{Ad})$ & 10.6 & 2.0 & 2.7 & 2.0 & 632 & 328 \\
\hline ICGV 99016 & TMV $2 \times(\mathrm{Ah} \times \mathrm{Ab} \times \mathrm{Ad})$ & 4.3 & 1.7 & 2.2 & 2.3 & 926 & 346 \\
\hline ICGV 86031 & F334-A-B-14 × NCAc 2214 & 11.8 & 2.2 & 2.3 & 6.7 & 484 & 600 \\
\hline ICGV 86590 & X14-4-B-19-B × PI 259747 & 8.1 & 2.0 & 1.5 & 4.7 & 1011 & 729 \\
\hline ICGV 86699 & $(\mathrm{Ab} \times \mathrm{Ad}) \times \mathrm{NC} 2$ & 6.6 & 1.5 & 1.5 & 2.0 & 1039 & 507 \\
\hline TMV 2 & & 8.4 & 4.7 & 3.8 & 9.0 & 354 & 498 \\
\hline M 13 & & 6.7 & 1.3 & 1.7 & 4.3 & 390 & 413 \\
\hline NCAc 343 & & 8.5 & 1.3 & 1.8 & 4.3 & 417 & 346 \\
\hline ICGV 87160 & Ah $65 \times$ NCAc 17090 & 6.9 & 2.3 & 2.7 & 6.3 & 1298 & 676 \\
\hline Robut 33-1 & & 7.2 & 2.0 & 1.5 & 7.3 & 344 & 647 \\
\hline $\mathrm{SE}$ & & \pm 1.8 & \pm 0.3 & \pm 0.6 & \pm 0.3 & \pm 158 & \pm 56 \\
\hline LSD & & 5.22 & 0.79 & 1.57 & 1.03 & 452 & 161 \\
\hline$F(\mathrm{df}=59)$ & & 1.55 & 9.98 & 1.20 & 44.80 & 2.81 & 5.18 \\
\hline$P$ & & 0.12 & 0.001 & 0.30 & 0.001 & 0.003 & 0.001 \\
\hline
\end{tabular}

${ }^{a}$ Ac, Arachis cardenasii; Ab, Arachis batizocoii; Ah, Arachis hypogaea; Ad, Arachis duranensis; As, Arachis stenosperma; Av, Arachis villosa; Aco, Arachis correntina.

${ }^{b}$ Damage rating, see Table 1.

A. cardenasii (ICG 8216), A. ipaensis (ICG 8206), A. stenophylla (ICG 8215), A. sylvestris (ICG14915), A. appressipila (ICG 8945 and ICG 8946), and Arachis rigonii (ICG 8904) have high levels of resistance to $S$. litura (resistance index $<1.0$ ) compared with the commercial cultivar, TMV 2 (resistance index 16.3). Seven accessions (ICG 11550, ICG 11555, ICG 13242, ICG 8197, ICG 13177, ICG 13178, and ICG 13212) of the wild Arachis spp. were as susceptible (resistance index $10.8-15.9$ ) to the $S$. litura as the cultivated groundnut cultivars ICGV 86699 and TMV 2 (resistance index 18.8 and 16.3).

Leaf feeding by S. litura larvae was significantly and positively associated with loss in plant biomass both on wet $(r=0.58, P=0.01)$ and dry $(r=0.42, P=0.05)$ weight basis, larval survival $(r=0.59, P=0.01)$, and larval weight $(r=0.53, P=0.01)$. Larval survival showed a significant and positive association with loss in plant biomass on wet weight basis $(r=0.43, P=$ $0.05)$. Larval weight was also strongly correlated with loss in plant biomass on wet $(r=0.54, P=0.01)$ and dry $(r=0.62, P=0.01)$ weight basis. There was no association between larval survival and the larval weights. The results suggested that genotypes suffering low leaf damage also showed adverse effects (antibiosis) on development of S. litura larvae.

Relative Susceptibility of Lines Derived from Wild Relatives to Insect Pests under Field Conditions. There were significant differences $(\mathrm{df}=59)$ in $H$. armigera $(F=9.98, P=0.001)$, and rust/late leaf spot
$(F=44.80, P=0.001)$ damage in the lines derived from wild Arachis spp. (Table 4). Genotypes ICGV 99009, ICGV 99016, and ICGV 99002 were less susceptible (damage rating $<5.0$ ) to leaf miner compared with NCAc 343 (damage rating 8.5). ICGV 99009, ICGV 99002, ICGV 99004, ICGV 86950, ICGV 86699, NCAc 343, M 13, and Robut 33-1 showed resistance to leaf feeding by $H$. armigera and S. litura (damage rating $<2.0$ compared with 4.7 and 3.8 , respectively, in TMV 2). However, the differences in leaf damage by S. litura were not significant $(F=1.20, P=0.30)$. Several lines showed high levels of resistance to rust and late leaf spot (damage rating $<2.3$ compared with 7.3 in Robut 33-1 and 9.0 in TMV 2). Pod yield differed significantly among the genotypes tested $(\mathrm{df}=59)$ during the 1999 rainy $(F=2.81, P=0.003)$ and the $1999 / 2000$ postrainy $(F=5.18, P<0.001)$ seasons. During the 1999 rainy season, four lines derived from wide crosses yielded 926-979 kg pods per ha compared with 10111298-kg pods per ha in ICGV 86590, ICGV 86699, and ICGV 87160; and 354-kg pods per ha in TMV 2-the commercial check (Table 4). During the 1999-2000 post-rainy season, ICGV 99260, ICGV 99006, and ICGV 99004 yielded 494-507-kg pods per ha compared with $346-729-\mathrm{kg}$ pods per ha in the cultivated checks (Table 4). Five lines (ICGV 99007, ICGV 99009, ICGV 99002, ICGV 99003, and ICGV 99016) showing good yield potential during the rainy season, also showed less susceptibility to A. modicella, $H$. armigera, S. litura, and rust/late leaf spot. Differences in 
Table 5. Relative susceptibility of 12 lines derived from wild Arachis spp. and eight cultivated groundnut genotypes to leafhoppers, thrips, and peanut bud necrosis disease (PBND) under field conditions

\begin{tabular}{|c|c|c|c|c|c|c|}
\hline \multirow{3}{*}{ Genotype } & \multirow{3}{*}{ Pedigree $^{a}$} & \multicolumn{4}{|c|}{ Damage rating $^{b}$} & \multirow{3}{*}{$\begin{array}{r}\text { PBND } \\
(\%) \\
2000\end{array}$} \\
\hline & & \multicolumn{2}{|c|}{ Leafhopper } & \multicolumn{2}{|c|}{ Thrips } & \\
\hline & & $1999 / 2000$ & 2000 & 1999 & $1999 / 2000$ & \\
\hline ICGV 99259 & Chico $\times[$ Shulamith $\times(\mathrm{Ac} \times \mathrm{Ab})$ & 4.0 & 4.0 & 5.3 & 3.7 & 9.9 \\
\hline ICGV 99260 & ICGMS $42 \times(\mathrm{Ah} \times \mathrm{Ac})$ & 4.0 & 4.0 & 4.7 & 5.7 & 15.5 \\
\hline ICGV 99006 & $\mathrm{Ah} \times \mathrm{Ac}$ & 2.7 & 2.0 & 3.0 & 5.3 & 17.6 \\
\hline ICGV 99007 & $\mathrm{Ah} \times \mathrm{Ac}$ & 5.3 & 3.7 & 3.7 & 2.3 & 15.6 \\
\hline ICGV 99001 & $\mathrm{Ah} \times(\mathrm{Ad} \times \mathrm{As})$ & 3.3 & 2.7 & 3.3 & 3.0 & 20.4 \\
\hline ICGV 99009 & Robut $33-1 \times$ Av & 5.3 & 2.3 & 3.3 & 3.3 & 13.9 \\
\hline ICGV 99002 & $($ Chico $\times$ Shulamith $) \times($ Aco $\times$ Ab $)$ & 4.0 & 6.0 & 4.7 & 3.7 & 9.3 \\
\hline ICGV 99003 & $\mathrm{Ah} \times(\mathrm{Ad} \times \mathrm{As})$ & 4.7 & 3.3 & 3.3 & 2.0 & 11.9 \\
\hline ICGV 99010 & $(\mathrm{Ah} \times \mathrm{Ac}) \times \mathrm{T} 900$ & 3.0 & 2.0 & 3.0 & 2.7 & 24.0 \\
\hline ICGV 99004 & $\mathrm{TMV} 2 \times(\mathrm{Ah} \times \mathrm{Ac})$ & 3.7 & 4.0 & 4.7 & 4.7 & 13.0 \\
\hline ICGV 99005 & $\mathrm{TMV} 2 \times(\mathrm{Ah} \times \mathrm{Ab} \times \mathrm{Ad})$ & 3.7 & 5.0 & 2.3 & 4.0 & 21.0 \\
\hline ICGV 99016 & TMV $2 \times(\mathrm{Ah} \times \mathrm{Ab} \times \mathrm{Ad})$ & 4.7 & 3.3 & 4.0 & 3.0 & 13.7 \\
\hline ICGV 86031 & F334-A-B-14 × NCAc 2214 & 3.7 & 2.0 & 3.3 & 3.0 & 14.1 \\
\hline ICGV 86590 & X14-4-B-19-B × PI 259747 & 2.7 & 3.3 & 3.0 & 4.0 & 10.9 \\
\hline ICGV 86699 & $(\mathrm{Ab} \times \mathrm{Ad}) \times \mathrm{NC} 2$ & 4.3 & 3.3 & 5.3 & 3.3 & 12.4 \\
\hline TMV 2 & & 5.7 & 4.7 & 6.7 & 6.0 & 29.9 \\
\hline M 13 & & 3.3 & - & 6.0 & 3.3 & - \\
\hline NCAc 343 & & 2.3 & 2.3 & 4.3 & 3.7 & 11.3 \\
\hline ICGV 87160 & Ah $65 \times$ NCAc 17090 & 4.0 & 3.7 & 5.3 & 4.0 & 15.2 \\
\hline Robut 33-1 & & 6.3 & 7.3 & 6.7 & 3.7 & 15.8 \\
\hline $\mathrm{SE}$ & & \pm 0.4 & \pm 0.7 & \pm 0.7 & \pm 0.7 & \pm 3.7 \\
\hline LSD & & 1.20 & 1.97 & 1.87 & 2.07 & 10.73 \\
\hline$F(\mathrm{df}=59)$ & & 2.16 & 4.15 & 3.83 & 2.13 & 1.92 \\
\hline$P$ & & 0.02 & 0.01 & 0.001 & 0.02 & 0.05 \\
\hline
\end{tabular}

\footnotetext{
${ }^{a}$ Ac, Arachis cardenasii; Ab, Arachis batizocoii; Ah, Arachis hypogaea; Ad, Arachis duranensis; As, Arachis stenosperma; Av, Arachis villosa; Aco, Arachis correntina.

${ }^{b}$ Damage rating, see Table 1; PBND, peanut bud necrosis disease.
}

susceptibility to leafhoppers $(F=2.16-4.15, P=0.02-$ $0.01)$, thrips $(F=2.13, P=0.02)$, and peanut bud necrosis disease $(F=1.92, P=0.05)$ were significant among the genotypes tested (Table 5). ICGV 99001 and ICGV 99010 showed multiple-resistance to leafhoppers and thrips. Incidence of peanut bud necrosis disease was $9.3-11.9 \%$ in ICGV 99259, ICGV 99002, ICGV 99003, ICGV 86590, and NCAc 343 compared with $29.9 \%$ incidence in TMV 2.

Relative Susceptibility of Lines Derived from Wild Relatives to S. litura Under No-Choice Conditions in the Greenhouse. There were significant $(\mathrm{df}=59)$ differences in leaf feeding $(F=4.13, P<0.001)$, larval weight $(F=3.54, P=0.01)$, and larval survival $(F=$ $2.97, P=0.002)$ of $S$. litura on the genotypes tested (Table 6). However, the differences in percentage loss in seedling biomass on wet $(F=1.30, P<0.23)$ and dry weight basis $(F=1.23, P<0.28)$ were not significant. Genotypes ICGV 99009, ICGV 99005, ICGV 86031, and ICGV 87160 suffered significantly lower leaf damage $(F=4.13, \mathrm{df}=59, P=0.001)$ compared with a damage rating of 7.0 in the commercial cultivar TMV 2, and 9.0 in ICGV 86699. Percentage loss in seedling weight was $<28.5 \%$ in ICGV 99260, ICGV 99010, ICGV 99005, ICGV 86590, and Robut 33-1 compared to 47.5-54.5\% loss in TMV 2. However, the differences between these genotypes were not significant $(P=0.05)$. Larval weights were significantly $(F=3.54, \mathrm{df}=59, P=$ $0.01)$ lower $(<50 \mathrm{mg})$ when the larvae were reared on ICGV 99260, ICGV 99007, ICGV 99001, ICGV 99009, ICGV 99010, ICGV 99004, ICGV 99005, ICGV 86031,
ICGV 86590, NCAc 343, and ICGV 87160 compared with those reared on TMV 2 (100 mg). Larval survival was also significantly $(F=2.97$, df $=59, P=0.002)$ lower $(<60 \%)$ when the larvae were reared on ICGV 99002, ICGV 99005, ICGV 86031, and ICGV 87160 compared with $93.3 \%$ larval survival in larvae reared on M 13. Resistance index was 0.9-2.8 in case of ICGV 99009 (derived from A. batizocoii), ICGV 99005 (derived from A. batizocoii and A. duranensis), and ICGV 87160 (derived from NCAc 17090) compared with 16.3 of the commercial cultivar TMV 2.

Association of Plant Morphological Characteristics of Wild Arachis spp. with Resistance to Insect Pests. Apical leaflet shape on the main stem, basal leaflet shape on primary laterals days to maturity, hypanthium length, leaflet hairiness on main stem, peg length, and standard petal width showed a negative, while basal leaflet width on main stem, and main stem hairiness showed a positive correlation with $H$. armigera damage (Table 7). Apical leaflet length on primary lateral, basal leaflet shape on primary lateral, days to maturity, flowers on main stem, growth habit, main stem hairiness, stipule adnation length, and main stem thickness showed a negative correlation while basal leaflet width, and stem pigmentation showed a positive correlation with leafhopper damage. Apical leaflet shape on the main stem, basal leaflet shape on the primary lateral, basal leaflet width on main stem, days to maturity, flowers on main stem, hypanthium length, leaflet hairiness on main stem, peg length, and stipule adnation length and width showed a negative 
Table 6. Relative susceptibility of 12 lines derived from wild Arachis spp. and eight cultivated groundnut genotypes to Spodoptera litura under no-choice cage tests

\begin{tabular}{|c|c|c|c|c|c|c|c|}
\hline \multirow[t]{2}{*}{ Genotype } & \multirow[t]{2}{*}{ Pedigree $^{a}$} & \multirow[t]{2}{*}{$\begin{array}{l}\text { Damage } \\
\text { rating }^{b}\end{array}$} & \multicolumn{2}{|c|}{$\begin{array}{c}\text { Seedling } \\
\text { biomass loss } \\
(\%)\end{array}$} & \multirow[t]{2}{*}{$\begin{array}{l}\text { Larval wt } \\
\quad(\mathrm{mg})\end{array}$} & \multirow[t]{2}{*}{$\begin{array}{c}\text { Larval } \\
\text { survival }(\%)\end{array}$} & \multirow[t]{2}{*}{$\begin{array}{l}\text { Resistance } \\
\text { index }\end{array}$} \\
\hline & & & Wet & Dry & & & \\
\hline ICGV 99259 & Chico $\times[$ Shulamith $\times(\mathrm{Ac} \times \mathrm{Ab})$ & 7.3 & 28.8 & 29.4 & 51.8 & 90.0 & 28.3 \\
\hline ICGV 99260 & ICGMS $42 \times(\mathrm{Ah} \times \mathrm{Ac})$ & 6.3 & 24.6 & 20.1 & 48.1 & 76.7 & 10.6 \\
\hline ICGV 99006 & $\mathrm{Ah} \times \mathrm{Ac}$ & 6.7 & 35.7 & 31.9 & 57.8 & 70.0 & 5.5 \\
\hline ICGV 99007 & $\mathrm{Ah} \times \mathrm{Ac}$ & 6.0 & 19.2 & 43.1 & 40.5 & 70.0 & 10.5 \\
\hline ICGV 99001 & $\mathrm{Ah} \times(\mathrm{Ad} \times \mathrm{As})$ & 6.0 & 28.1 & 26.6 & 47.8 & 70.0 & 15.6 \\
\hline ICGV 99009 & Robut $33-1 \times$ Av & 5.0 & 38.6 & 41.2 & 38.7 & 70.0 & 2.8 \\
\hline ICGV 99002 & $($ Chico $\times$ Shulamith $) \times($ Aco $\times \mathrm{Ab})$ & 6.0 & 44.7 & 48.5 & 69.6 & 56.7 & 9.9 \\
\hline ICGV 99003 & $\mathrm{Ah} \times(\mathrm{Ad} \times \mathrm{As})$ & 6.7 & 33 & 31.8 & 54.2 & 60.0 & 11.1 \\
\hline ICGV 99010 & $(\mathrm{Ah} \times \mathrm{Ac}) \times \mathrm{T} 900$ & 6.3 & 10 & 15.1 & 40.7 & 76.7 & 15.5 \\
\hline ICGV 99004 & TMV $2 \times(\mathrm{Ah} \times \mathrm{Ac})$ & 8.0 & 24.5 & 23.4 & 32.1 & 100.0 & 13.4 \\
\hline ICGV 99005 & TMV $2 \times(\mathrm{Ah} \times \mathrm{Ab} \times \mathrm{Ad})$ & 3.5 & 28.5 & 15.2 & 45.3 & 36.7 & 2.5 \\
\hline ICGV 99016 & TMV $2 \times(\mathrm{Ah} \times \mathrm{Ab} \times \mathrm{Ad})$ & 6.7 & 48.6 & 55 & 75.7 & 83.3 & 31.8 \\
\hline ICGV 86031 & F334-A-B-14 × NCAC 2214 & 5.0 & 26.6 & 27.6 & 45.2 & 50.0 & 4.7 \\
\hline ICGV 86590 & X14-4-B-19-B × PI 259747 & 7.5 & 23.8 & 19.7 & 48.6 & 80.0 & 24.8 \\
\hline ICGV 86699 & $(\mathrm{Ab} \times \mathrm{Ad}) \times \mathrm{NC} 2$ & 9.0 & 51.7 & 51.8 & 68.5 & 80.0 & 22.1 \\
\hline TMV 2 & & 7.0 & 47.5 & 54.4 & 100.1 & 56.7 & 16.3 \\
\hline M 13 & & 6.5 & 19.3 & 23.5 & 63.5 & 93.3 & 25.8 \\
\hline NCAC 343 & & 6.5 & 37.7 & 37.6 & 42.8 & 76.7 & 8.2 \\
\hline ICGV 87160 & Ah $65 \times$ NCAc 17090 & 2.5 & 27.4 & 31.5 & 25.2 & 26.7 & 0.9 \\
\hline $\begin{array}{c}\text { ROBUT } \\
33-1\end{array}$ & & 6.0 & 21 & 25.8 & 75.5 & 40.0 & 7.9 \\
\hline $\mathrm{SE}$ & & \pm 0.7 & \pm 9.7 & \pm 11.4 & \pm 9.4 & \pm 11.2 & \pm 6.2 \\
\hline LSD & & 2.03 & 27.77 & 32.63 & 26.8 & 31.98 & 17.79 \\
\hline$F(\mathrm{df}=59)$ & & 4.13 & 1.3 & 1.23 & 3.54 & 2.97 & 2.29 \\
\hline$P$ & & 0.001 & 0.23 & 0.28 & 0.01 & 0.002 & 0.023 \\
\hline
\end{tabular}

${ }^{a}$ Ac, Arachis cardenasii; Ab, Arachis batizocoii; Ah, Arachis hypogaea; Ad, Arachis duranensis; As, Arachis stenosperma; Av, Arachis villosa; Ac, Arachis correntina.

${ }^{b}$ Damage rating see Table 1.

association, while stem pigmentation showed a positive association with susceptibility to leaf diseases. In general, apical leaf shape on main stem, basal leaflet shape on the primary lateral, days to maturity, flowers

Table 7. Correlation coefficients between insect damage ratings and plant morphological characters in 30 accessions of wild Arachis spp.

\begin{tabular}{lllrl}
\hline & \multicolumn{3}{c}{ Correlation coefficient } \\
\cline { 2 - 5 } \multicolumn{1}{c}{ Trait } & H. armigera Leafhoppers & $\begin{array}{c}\text { Leaf } \\
\text { miner }\end{array}$ & $\begin{array}{l}\text { Rust/late } \\
\text { leaf spot }\end{array}$ \\
\hline Apical leaflet length-PL & -0.15 & $-0.46^{*}$ & 0.25 & -0.01 \\
Apical leaflet shape-MS & $-0.79^{* *}$ & -0.06 & -0.02 & $-0.70^{* *}$ \\
Basal leaflet length-MS & -0.13 & -0.29 & 0.02 & -0.17 \\
Basal leaflet shape-PL & $-0.44^{*}$ & $-0.66^{* *}$ & $0.45^{*}$ & $-0.47^{*}$ \\
Basal leaflet width-MS & $0.58^{* *}$ & $0.46^{*}$ & -0.28 & $0.52^{* *}$ \\
Bristles on leaflet margin & -0.18 & 0.31 & $-0.39^{*}$ & 0.36 \\
Days to maturity & $-0.53^{* *}$ & $-0.41^{*}$ & $0.47^{*}$ & $-0.52^{* *}$ \\
Flowers on main stem & -0.36 & $-0.42^{*}$ & $0.42^{*}$ & $-0.51^{* *}$ \\
Growth habit & -0.17 & $-0.45^{*}$ & -0.10 & -0.21 \\
Hypanthium length & $-0.77^{* *}$ & -0.23 & 0.06 & $-0.75^{* *}$ \\
Leaflet color & -0.30 & 0.40 & -0.08 & -0.20 \\
Leaflet hairiness-MS & $-0.50^{* *}$ & -0.34 & 0.15 & $-0.45^{*}$ \\
Peg length & $-0.50^{* *}$ & -0.32 & 0.38 & $-0.40^{*}$ \\
Standard petal length & $-0.45^{*}$ & -0.13 & 0.02 & -0.37 \\
Standard petal width & $-0.44^{*}$ & -0.02 & -0.01 & -0.33 \\
Main stem hairiness & $0.45^{*}$ & $-0.45^{*}$ & 0.13 & 0.28 \\
Stipule adnation length & -0.25 & $-0.45^{*}$ & 0.39 & $-0.40^{*}$ \\
Stipule adnation width & -0.18 & -0.19 & 0.32 & $-0.39^{*}$ \\
Stem pigmentation & 0.04 & $0.51^{* *}$ & -0.36 & $0.47^{*}$ \\
Main stem thickness & -0.21 & $-0.41^{*}$ & 0.34 & -0.27 \\
\hline & & & & \\
\hline
\end{tabular}

*, **, Correlation coefficient significant at $P=0.05$ and $P=0.01$, respectively. on the main stem, hypanthium length, leaflet hairiness, peg length, standard petal length, stipule adnation length and width, standard petal width, and main stem thickness showed a negative association with damage by $H$. armigera, leafhoppers, and rust/late leaf spot, but a positive association with damage by the leaf miner (Table 7). In contrast, basal leaflet width and stem pigmentation showed a positive association with damage by $H$. armigera, leafhoppers, and rust/late leaf spot, but a negative association with leaf miner damage (except apical leaf shape on main stem and stipule adnation width). However, some of the correlation coefficients were not significant at $P=0.05$.

Stepwise regression analysis indicated that leaf damage by $H$. armigera (HaDR) was largely influenced by days to maturity (DM), hypanthium length (HL), leaflet hairiness (LH), and standard petal markings $(\mathrm{SPM})$, where $\mathrm{HaDR}=7.86^{* *}-0.007 \mathrm{DM}^{*}-$ $0.021 \mathrm{HL}^{* *}+0.093 \mathrm{LH}-0.718 \mathrm{SPM}^{* * *}$ (coefficient of determination $\left.\left(R^{2}\right)=78.0 \%\right)(* * *$ regression coefficients significant at $P<0.05$ and $P<0.01$, respectively). Basal leaflet width (BLW), main stem hairiness (MSH), and stipule adnation length (SAL) explained $61.2 \%$ of the variation in leafhopper damage $(\mathrm{EkDR})$, where $\mathrm{EkDR}=1.45^{* *}+0.06 \mathrm{BLW}^{* *}-$ $0.114 \mathrm{MSH}^{*}-0.047 \mathrm{SAL}^{*}\left(R^{2}=61.2 \%\right)$. Basal leaflet width (BLW) and stipule adnation width (SAW) explained $44.3 \%$ of the variation $\left(R^{2}\right)$ in rust/late leaf spot severity, where LdDR $=1.34+0.191 \mathrm{SAW}^{*}$ $0.353 \mathrm{SAW}^{*}$ 
Table 8. Correlation coefficients between Spodoptera litura damage, larval survival, and weight with morphological characteristics of 21 accessions of Arachis spp

\begin{tabular}{|c|c|c|c|c|c|}
\hline \multirow{2}{*}{ Trait $^{a}$} & \multirow{2}{*}{$\begin{array}{c}\text { Damage } \\
\text { rating }^{b}\end{array}$} & \multirow{2}{*}{$\begin{array}{c}\text { Larval } \\
\text { survival } \\
(\%)\end{array}$} & \multicolumn{2}{|c|}{ Seedling weight loss (\%) } & \multirow{2}{*}{$\begin{array}{c}\text { Larval } \\
\text { weight } \\
\text { (mg) }\end{array}$} \\
\hline & & & Dry & Wet & \\
\hline Apical leaflet length-PL & $-0.38^{*}$ & -0.30 & $-0.41 *$ & $-0.46^{*}$ & -0.21 \\
\hline Apical leaflet shape-MS & -0.23 & 0.06 & $-0.68 * *$ & $-0.57 * *$ & $-0.71 * *$ \\
\hline Apical leaflet shape-PL & $-0.38^{*}$ & -0.31 & $-0.44^{*}$ & $-0.46^{*}$ & -0.32 \\
\hline Basal leaflet length-MS & $-0.36^{*}$ & $-0.48 *$ & $-0.58 * *$ & $-0.62 * *$ & -0.30 \\
\hline Basal leaflet shape-PL & $-0.54^{* *}$ & -0.25 & $-0.43^{*}$ & $-0.42 *$ & $-0.54 * *$ \\
\hline Basal leaflet width-MS & 0.07 & -0.13 & 0.07 & 0.01 & 0.37 \\
\hline Bristles on leaflet margin & $0.57^{* *} *$ & $0.55^{* *}$ & 0.13 & 0.18 & 0.23 \\
\hline Days to maturity & $-0.39^{*}$ & -0.19 & $-0.53 * *$ & $-0.48^{*}$ & $-0.56^{* *}$ \\
\hline Flowers on main stem & $-0.40^{*}$ & -0.35 & -0.29 & -0.29 & $-0.45^{*}$ \\
\hline Growth habit & -0.06 & -0.17 & $-0.57 * *$ & $-0.47^{*}$ & -0.25 \\
\hline Hypanthium length & $-0.49 * *$ & -0.10 & $-0.78 * *$ & $-0.71 * *$ & $-0.80 * *$ \\
\hline Leaflet color & -0.25 & 0.02 & -0.34 & $-0.45^{*}$ & -0.27 \\
\hline Leaflet hairiness-MS & -0.26 & 0.01 & $-0.74 * *$ & $-0.61 * *$ & $-0.62 * *$ \\
\hline Peg length & $-0.53^{* *}$ & -0.28 & $-0.42 *$ & $-0.47^{*}$ & $-0.66^{* *}$ \\
\hline Rachis length-MS & $-0.38^{*}$ & $-0.49 * *$ & $-0.51^{* *}$ & $-0.55^{* *}$ & -0.04 \\
\hline Standard petal length & -0.09 & -0.10 & $-0.63 * *$ & $-0.61^{* *}$ & $-0.39 *$ \\
\hline Standard petal markings-FF & 0.30 & 0.22 & -0.17 & -0.14 & -0.28 \\
\hline Main stem hairiness & -0.22 & -0.37 & 0.18 & 0.15 & 0.19 \\
\hline Stipule adnation length & $-0.62^{* *}$ & -0.26 & $-0.62 * *$ & $-0.60^{* *}$ & $-0.52 * *$ \\
\hline Stipule adnation width & $-0.72^{* *}$ & $-0.49 * *$ & $-0.68 * *$ & $-0.73 * *$ & $-0.53^{* *}$ \\
\hline Stem pigmentation & 0.07 & 0.14 & -0.19 & -0.22 & 0.12 \\
\hline Standard petal width & -0.06 & -0.05 & $-0.71^{* *}$ & $-0.68 * *$ & -0.35 \\
\hline Main stem thickness & $-0.54^{* *}$ & $-0.42 *$ & -0.29 & $-0.40^{*}$ & -0.26 \\
\hline
\end{tabular}

*, ** Indicate significant correlation coefficient at $P=0.05$ and 0.01 , respectively

${ }^{a}$ MS, main stem; PL, primary lateral; FF, front face.

${ }^{b}$ Damage rating, see Table 1 .

Leaflet length, color, shape and hairiness, days to maturity, growth habit, hypanthium length, peg and rachis length, standard petal length and width, stipule adnation length and width, and main stem thickness showed a negative association with damage by S. litura (Table 8). However, bristles on the leaflet margin showed a positive association with susceptibility to this insect. Stepwise regression analysis indicated that apical leaflet shape (ALS), basal leaflet length (BLL), bristles on leaflet margin (BLM), days to maturity (DM), flowers on the main stem (FMS), hypanthium length (HL), peg length (PL), stipule adnation length (SAL), and main stem thickness (MST) explained $94.4 \%$ of the variation in leaf damage rating (DR) by S. litura larvae, where $\mathrm{DR}=4.54^{* *}-0.14 \mathrm{ALS}^{*}+$ $0.11 \mathrm{BLL}^{* *}+1.37 \mathrm{BLM}^{* *}+0.20 \mathrm{DM}+3.13 \mathrm{FMS}^{* *}-$ $0.03 \mathrm{HL}^{*}-0.02 \mathrm{PL}^{* *}-0.84 \mathrm{SAL}^{*}-0.64 \mathrm{MST}^{*}\left(R^{2}=\right.$ $94.4 \%)$. Hypanthium length (HL) explained $44.3 \%$ of the variation in larval weight $(\mathrm{Lwt})$, where Lwt $=$ $70.3^{* *}-0.79 \mathrm{HL}^{*}$. The plant characteristics showing significant regression coefficients following stepwise regression analysis may be explored for use as marker traits in crop improvement when selecting groundnuts for resistance to S. litura.

Genotypic Diversity Based on Principal Component Analysis. Principal component analysis based on insect damage and plant morphological data for 21 accessions (for which the complete data set was available) placed the genotypes into five groups (Fig. 1A). Accessions ICG 8130, ICG 8963, and ICG 8970 (A. paraguariensis), ICG 8215 (A. stenophylla), ICG 11557 (A. matiensis) and ICG 8945 (A. appressipila) were placed in group I; ICG 8946 (A. appressipila) in group
II; ICG 8164 (A. kempff-mercadoi), ICG 8131 (A triseminata), ICG 8190 (A. hoehnei), ICG 8216 (A. cardenasii), and ICG 11550 (A. duranensis) in group III; ICG 8125 and ICG 13171 (A. stenosperma), ICG 8197 (A. monticola), ICG 8201 and ICG 8203 (A. duranensis) in group IV; and ICG 11551 (A. benensis) and ICG 11555 (A. duranensis) in group V.

Based on leaf feeding, loss in plant biomass, and larval survival and weight of $S$. litura under no-choice conditions, the accessions were placed in five groups (Fig. 1B): ICG 8946 (A. appressipila) in group I; ICG 8130 and ICG 8970 (A. paraguariensis), ICG 8215 (A stenophylla), and ICG 8945 (A. appressipila) in group II; ICG 8131 (A. triseminata), ICG 8164 (A. kempffmercadoi), ICG 8190 (A. hoehnei) and ICG 8216 (A. cardenasii) in group III; ICG 11551 (A. benensis), and ICG 11555 (A. duranensis) in group IV; and ICG 8125 and ICG 13171 (A. stenosperma), ICG 8197 (A. monticola), and ICG 8201, ICG 8203, and ICG 11550 (A. duranensis) in group $\mathrm{V}$. The results indicated that there is considerable diversity in relative susceptibility of different accessions of wild Arachis spp. for resistance to different insect pests, and these differences can be exploited to increase the levels, and diversify the bases of resistance to insects in cultivated groundnut.

\section{Discussion}

The majority of accessions of A. hypogaea are susceptible to lepidopterous pests (Wightman et al. 1990). Results of the present studies have shown that some of the wild relatives possess high levels of resis- 

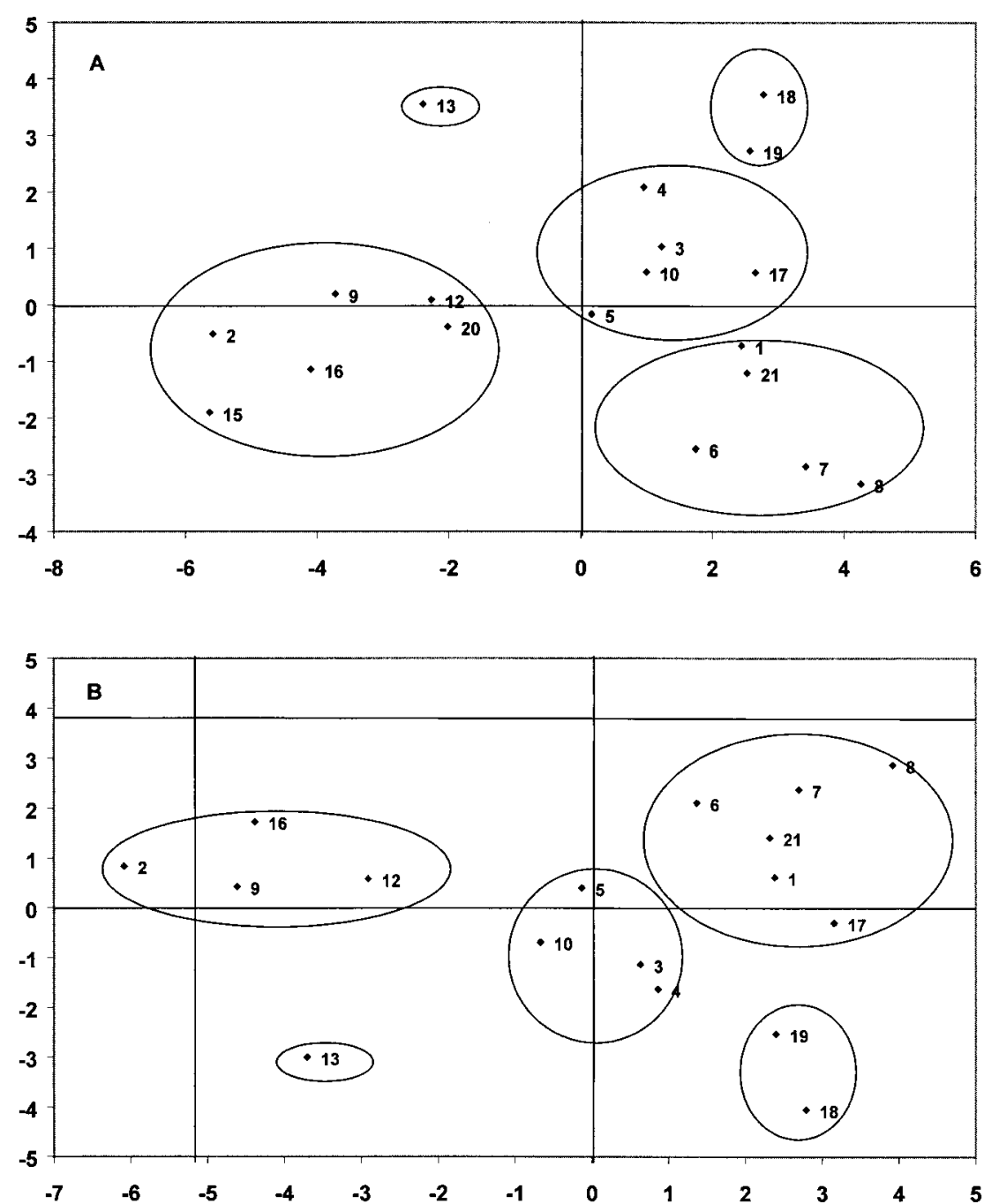

Fig. 1. Principal component analysis of 21 Arachis accessions based on insect damage and plant morphological characters (A); and leaf feeding, larval survival, and development of S. litura (B). (1 = ICG 8125, $2=$ ICG 8130, $3=$ ICG 8131, $4=$ ICG 8164, 5 = ICG 8190, 6 = ICG 8197, $7=$ ICG 8201, $8=$ ICG 8203, $9=$ ICG 8215, $10=$ ICG 8216, $11=$ ICG 8904, $12=$ ICG 8945, $13=$ ICG 8946, $14=$ ICG 8959, $15=$ ICG 8963, $16=$ ICG 8970, $17=$ ICG 11550, $18=$ ICG $115511,19=$ ICG 11555 , $20=$ ICG 11557, and $21=$ ICG 13171).

tance to insects feeding on groundnut. A few lines with resistance to insects have been identified in cultivated groundnuts and wild Arachis spp. (Hammons 1970, Johnson et al. 1977, Barfield et al. 1980, Garner and Lynch 1981, Lynch et al. 1981, Stalker and Campbell 1983, Stalker et al. 1984, Amin 1985, Lynch 1990). Some of the wild Arachis spp. have been reported to disrupt the survival and development of S. frugiperda (Lynch et al. 1981). Stevenson et al. (1993) reported $>90 \%$ mortality of neonate larvae of $S$. litura fed on the excised leaves of A. batizogaea (ICG 8901), A. kempffmercadoi (ICG 8959 and ICG 13159), A. appresipilla (PI 2261877), A. paraguariensis (ICG 8964), and A. villosa (ICG 13169) compared with $<20 \%$ mortality on TMV 2. In addition to the physical characteristics of the leaves, secondary plant substances are important in the resistance of wild relatives to S. litura. Lynch et al. (1981) found A. burkartii (PI 261851) and A. villosa (PI 261872) to be resistant, and A. monticola, A. stenosperma (ICG 8125), and A. batizogaea (ICG 8901) to be susceptible to $S$. frugiperda, whereas Arachis cardenasii (ICG 8216) and A. monticola (PI 405933) resulted in larval mortality. Arachis glandulifera (PI 468342), A. batizocoi (ICG 8211), A. ipaensis (ICG 8206), A. chacoense (PI 276235), and A. paraguariensis (PI 262842) have shown a resistant reaction to $S$. frugiperd $a$ and thrips, and these species differ in lipid composition, of which $n$-alkanes are the major component (Yang et al. 1993).

There was considerable variation in the relative susceptibility of different accessions of A. cardenasii, A. duranensis, A. kempff-mercadoi, A. monticola, A. 
stenosperma, A. paraguariensis, and A. appressipila, for which more than one accession was tested for resistance to insects. Accessions belonging to A. cardenasii, A. duranensis, A. kampff-mercadoi, A. monticola, A. stenosperma, A. paraguariensis, Arachis pusilla, and A. triseminata showed multiple resistance to leaf miner (A. modicella), H. armigera, E. kerri, and rust/late leaf spot; of which A. cardenasii (ICG 8216), A. duranensis (ICG 13242, except for leaf feeding), A. ipaensis (ICG 8206), A. paraguariensis (ICG 8130), and A. appressipila (ICG 8946) also showed resistance to leaf feeding and antibiosis to S. litura under no-choice tests in the greenhouse. Some of the accessions belonging to A. duranensis, A. ipaensis, A. monticola, and A. appressipila showed a susceptible reaction to leaf feeding by A. modicella, H. armigera, and E. kerri. Some of the accessions suffered heavy leaf feeding by S. litura larvae under no-choice conditions, but resulted in slow growth of the larvae because of poor nutritional quality of the food and/ or presence of secondary plant substances (Stevenson et al. 1993). Very high levels of antibiosis were observed in accessions belonging to $A$. benensis, A. cardenasii, A. hoehnei, A. ipaensis, A. kempff-mercadoi, A. paraguariensis, A. stenophylla, A. sylvestris, A. appressipila, and A. triseminata.

Association of plant morphological characteristics in general was in the same direction (positive or negative) for damage by $H$. armigera, leafhoppers, and leaf diseases, but the reverse was true in case of leaf miner. Therefore, careful planning is needed while developing groundnut cultivars with resistance to insect pests. Several plant morphological characteristics showed significant correlation and regression coefficients with damage by $H$. armigera, leafhoppers, and leaf diseases. The plant characteristics showing significant regression coefficients following stepwise regression can be considered as a selection criteria in crop improvement while selecting groundnuts for resistance to S. litura. Principal component analysis based on insect damage and morphological data placed the genotypes into five groups. The genotypes placed into the same group have the similar combination of characteristics and are distinct from genotypes placed into other groups. Utilization of genotypes (with resistance to the same or different insects) placed into different groups will be useful for increasing the levels and diversifying the basis of resistance to the target pest or developing lines with multiple resistance to insect pests and diseases. Utilization of genotypes placed into distinct groups in a crossing program will also lead to development of lines with stable and durable resistance, as they are likely to have different mechanisms or genes for resistance to the insect pests.

\section{Acknowledgments}

We thank B. U. Singh, Madhusudan Reddy, V. V. Rao and J. R. Rao for their help in carrying out these experiments, and P. J. Bramel for her encouragement to carryout these studies.

\section{References Cited}

Amin, P. W. 1985. Resistance of wild species of groundnut to insect and mite pests. pp. 57-61. In J. P. Moss [ed.], Proceedings, international workshop on cytogenetics of Arachis, 1 October-2 November 1983. International Crops Research Institute for the Semi-Arid tropics (ICRISAT), Patancheru, Andhra Pradesh, India.

Barfield, S. S., J. W. Smith, Jr., C. Carlysle, and E. R. Mitchell. 1980. Impact of peanut phenology on select population parameters of fall armyworm. Environ. Entomol. 9: 381384.

Garner, J. W., and R. E. Lynch. 1981. Fall armyworm leaf consumption and development on Florunner peanuts. J. Econ. Entomol. 74: 191-193.

GENSTAT. 2000. GENSTAT release 4.2, 5th ed. Lawes Agricultural Trust, VSN International Limited, Oxford, United Kingdom.

Hammons, R. O. 1970. Registration of Southeastern Runner 56-15 peanuts. Crop Sci. 10: 27.

(ICRISAT) International Crops Research Institute for the Semi-Arid Tropics. 1992. The medium term plan. International Crops Research Institute for the Semi-Arid Tropics (ICRISAT), Patancheru, 502 324, Andhra Pradesh, India.

[IBPGR] International Board for Plant genetic Resources, and [ICRISAT] International Crops Research Institute for the Semi-Arid Tropics. 1992. Descriptors for groundnut. International Board for Plant Genetic Resources, Rome, Italy; and International Crops Research Institute for the Semi-Arid Tropics, Patancheru, Andhra Pradesh, India.

Iezzoni, A. F., and M. P. Pitts. 1991. Applications of principal component analysis to horticultural research. HortScience 26: 334-338.

Johnson, D. R., J. C. Wynne, and W. V. Campbell. 1977. Resistance of wild species of Arachis to the twospotted spider mite, Tetranychus urticae. Peanut Sci. 4: 9-11.

Lynch, R. E. 1990. Resistance in peanut to major arthropod pests. Fla. Entomol. 73: 360-363.

Lynch, R. E., W. D. Branch, and J. W. Garner. 1981. Resistance of Arachis species to the fall armyworm, Spodoptera frugiperda. Peanut Sci. 8: 106-109.

Panchabhavi, K. S., and L. R. Nethradani Raj. 1987. Yield of groundnut as affected by varying larval density of Spodoptera litura. Indian J. Agric. Sci. 57: 525-527.

Sharma, H. C., G. Pampapathy, and R. Kumar. 2002. Techniques to screen groundnuts for resistance to the tobacco armyworm, Spodoptera litura (Lepidoptera: Noctuidae) under no-choice cage conditions. Peanut Sci. 29: 35-40.

Stalker, H. T., and W. V. Campbell. 1983. Resistance of wild species of peanut to an insect complex. Peanut Sci. 10: $30-33$.

Stalker, H. T., W. V. Campbell, and J. C. Wynne. 1984. Evaluation of cultivated and wild peanut species for resistance to the lesser corn stalk borer, Elasmopalpus lignosellus (Lepidoptera: Pyralidae). J. Econ. Entomol. 77: 53-57.

Stevenson, P. C., W. M. Blaney, M.S.J. Simmonds, and J. W. Wightman. 1993. The identification and characterization of resistance in wild species of Arachis to Spodoptera litura (Lepidoptera: Noctuidae). Bull. Entomol. Res. 83: 421-429.

Taneja, S. L., and K. Leuschner. 1985. Methods of rearing, infestation and evaluation for Chilo partellus resistance in sorghum, pp. 178-185. In Proceedings, International Sorghum Entomology Workshop, 15-21 July 1984, Texas A\&M University, College Station, TX. International 
Crops Research Institute for the Semi-Arid Tropics (ICRISAT), Patancheru 502 324, Andhra Pradesh, India.

Wightman, J. A., and P. W. Amin. 1988. Groundnut pests and their control in the semi-arid tropics. Trop. Pest Manage. 34: 218-228.

Wightman, J. A., K. M. Dick, G. V. Ranga Rao, T. G. Shanower, and C. G. Gold. 1990. Pests of groundnut in the semi-arid tropics, pp. 243-322. In S. R. Singh [ed.], Insect pests of legumes. Longman and Sons Ltd., New York.
Yang, G., K. E. Espelie, J. W. Todd, A. K. Culbreath, R. N. Pittman, and J. W. Demski. 1993. Cuticular lipids from wild and cultivated peanuts and the relative resistance of these peanut species to fall armyworm and thrips. J. Agric. Food Chem. 42: 814-818.

Received for publication 10 May 2002; accepted 30 June 2003. 